\title{
African Muslim Leaders and Turkey's Diyanat
}

Turkish-African relations began with the formation of the Ottoman Empire. Early relations were confined to parts of modern-day Tunisia, Libya and Egypt, which the empire ruled for centuries. Later on, the empire spread to other parts of Africa, as shown by such emerging scholars as Hatice Ugur, who wrote Osmanli Afrikasi'nda Bir Sultanlik Zengibar (Istanbul: 2005), and the scholarly works of Eric Germaine and others. Their research has been bolstered by the variety of extant documents that still need to be stud- 
ied and explored (cf. A. Kavas, ed. Solidarity of Ottoman-African Muslims: Under the Light of the Documents [Istanbul: 2006]). However, emerging African scholars interested in these manuscripts will have to be trained in and come to grips with Ottoman Turkish before making any headway.

Renewed efforts are now undeway to forge links with Africa's Muslim communities and representatives. The Research Center for Islamic History, Art, and Culture (IRCICA), an international institution that falls under the auspices of the Organization of Islamic Conference (OIC), has created the necessary opportunities to cement and strengthen links with African Muslim communities via specific structures, such as the Islamic University of Uganda and the University of Johannesburg. In the wake of these significant efforts, the Presidency of Religious Affairs (more popularly known in Turkey as the Diyanat [hereinafter Presidency]) has also shown its desire to pursue external relations with religious communities outside Turkey. Over the past few years, the Presidency has played a significant role in "religious affairs" both in and beyond Turkey in order to pursue its religious portfolio and religious agenda. Although the predominantly Muslim societies of the Muslim heartlands view Turkey, in general, as the most secular Muslim society, a strand of religiosity has been observed in its various social levels and sectors. Therefore, Turkish society cannot be said to be exclusively secular.

This historical event was organized under the auspices of the Presidency and the ministerial leadership of Ali Bardakoglu, author of Religion and Society: New Perspectives from Turkey (Ankara: 2006). Held in Istanbul during 1-3 November 2006, it focused on the "Meeting of Religious Leaders of Muslim Countries and Communities in Africa," and drew representatives from many sub-Saharan states and selected North African countries.

Since the Presidency is an integral part of the Turkish government's structure, the official opening ceremony took place where Kamal Ataturk lived while leading the new republic. The special guests were addressed by a Turkish state minister and other representatives, such as Algeria's minister of culture and the OIC's secretary general. The organization's president, Ali Bardakoglu, opened the official proceedings by emphasizing religion's importance and relevance in human affairs, pointing out the shared values that connect religious communities, and commenting upon the distinction between religion and culture as well as the recognition of Africa's rich human, material, and religio-cultural resources.

Shaykh Hissin Ababakar, Mufti of Chad and one of the African Muslim leaders, spoke on behalf of the invited African delegation. The shaykh lauded Turkey for hosting this meeting, stressed the need for cooperation, and suggested how Turkey can contribute by establishing a permanent sec- 
retariat to advance Turkish-African relations. Turkish Minister of State Mehmet Aydin discussed identity as an important frame within which to understand contemporary developments and conflicts. He dwelled on how mutual cooperation could help resolve communal and international problems. However, he cautioned, there is no certainty of finding permanent solutions. Apart from the opening Qur'anic recitation and official speeches, a short interesting documentary entitled "I Am Africa" was also screened.

The first session focused on "Reflections on the History and Future of Religious and Cultural Relationships between African Islamic Countries and Communities in Turkey." It was introduced by Ahmad Kavas, a Turkish specialist on West African Islam and Muslims and an associate professor at the University of Ankara, and Muhammad Bakary, a Kenyan scholar at Istanbul's Fateh University. Kavas provided a historical perspective of TurkishAfrican relations and explained, using extant documents, the nature of the connections that had been forged and the opportunities for future ties. Bakary expounded upon the unprecedented overtures made by a secular state, such as Turkey, to African religious leaders. He contextualized this by referring to the Ottoman Empire's important role in Muslim affairs as well as the patronage displayed by its political and religious leaders. After identifying the common strands, he commented upon how the British Commonwealth works and continues to connect the former colonial master with its former colonies. In his concluding remarks, he mentioned areas of possible cooperation.

The chairperson then identified sets of representatives from among the African Muslim leaders to make short five-minute presentations on the status of Islam and Muslims in their respective countries. Representatives came from, among others, Kenya, Cameroon, Madagascar, Mauritius, Mauritania, Mali, Ivory Coast, Senegal, and South Africa.

The second day featured three separate but interconnected sessions. Each session was opened by scholarly input from Turkish scholars (many of whom are attached to Istanbul University, Ankara University, or the Presidency) on the identified themes. The opening session, the "History of Islamic Propagation and Islam Today in Africa," was followed by the "Religious Identity in the Process of Globalization: Basic Approaches and Attitudes in Preserving Cultural Heritage." The day's concluding session looked at "Opportunities of Cooperation between African Islamic Countries and Communities and Turkey in the Fields of Religious Education and Services." Azab Bey (Turkey) and Hasan Karagah (Turkey) dealt with the issue of identity. Bey stated that the question of identity is both crucial and intimately connected to the concept of "nation." He also elaborated upon the need for a "civilizational identity," with religion as a means of integra- 
tion. Karagah argued that since religious identity is embedded in the process of globalization, there is no need for a "religious identity." This problematic and highly debatable thesis was not, unfortunately, countered after his presentation.

The final day was set aside for a general evaluation of the event. Bardakoglu asked several African representatives to share the platform with him. In this concluding session, a fairly detailed list of sixteen recommendations designed to cement and strengthen relations between Turkey and Africa's Muslims communities, which had been proposed before the concluding session, were read out and accepted. On the whole, this historical meeting was an important and successful initiative that the Presidency both suggested and followed up on. In fact, the its input can best be described as part of today's Track II diplomatic efforts.

A few issues were brought to the committee's attention. It will suffice, for the purposes of this brief report, to mention only two. First, the panels did not include a presenter from the African delegations. Thus the proceedings seem to have come across as a monologue rather than a detailed dialogue. Given that this event may be described as a test case, it is assumed that this oversight will be rectified before future meetings are held. Second, most of the African Muslim leaders were theologians. Such a meeting requires the contributions of other social sectors, for Muslim leaders are found in the social and health sciences, the economic and management sectors, and in many other areas. Muslim leaders have emerged from most of these sectors and thus form an important and integral part of the community's collective leadership. Today, Muslim theologians are only trained in certain traditional areas and thus cannot respond to each issue affecting their communities.

In any event, the Presidency planned this meeting with the idea of soliciting relevant communal facts from the various African Muslim representatives and with the intention of hosting and structuring future meetings on a more informed and representative basis. There is little doubt that the Presidency from this mainly secular (Muslim) state has entered a neglected area of international relations and explored an important dialogue track that other secular states may wish to follow. This meeting has laid an important foundation for future gatherings and conferences between Turkey and Africa's Muslim organizations. And, it most definitely contributed and added to those that have been initiated by similar institutions. 